\title{
JPMS
}

Jurnal Pengabmas Masyarakat Sehat

ARTIKEL HASIL PENGABDIAN KEPADA MASYARAKAT

URL artikel: http://ejournal.poltekkes-denpasar.ac.id/index.php/JPMS/article/view/jpms1408

\section{Penyuluhan Pada Ibu Nifas Mengenai Perawatan Tali Pusat Di Desa Ruta}

\author{
Rusnani Martahan $^{1 \mathrm{k}}$; Sukma Kabau ${ }^{1}$ \\ ${ }^{1}$ Sekolah Tinggi Ilmu Kesehatan Maluku Husada, DIII Kebidanan \\ Email penulis korespondensi $\left({ }^{\mathrm{K}}\right)$ : rusnani.martahan.rahman18@gmail.com
}

\begin{abstract}
The umbilical cord is the main entry point for systemic infections in newborns. In general, umbilical cord care aims to prevent infection and accelerate the breakdown of the umbilical cord. Basically, umbilical cord infection can be prevented by doing good and correct umbilical cord care, namely with the principle of dry and clean care. Many opinions about the best way to care for the umbilical cord. One of the efforts that can be made to reduce infant morbidity and mortality is by providing effective health services to the community regarding the care of the baby's umbilical cord. In carrying out these efforts, human resources who have the ability to provide quality services are needed, namely by providing health education to the community, so that the knowledge possessed by the community is expected to influence people's behavior towards health
\end{abstract}

Keywords: Childbirth, Umbilical Cord Care.

\section{Pendahuluan}

Tali pusat merupakan jalan masuk utama infeksi sistemik pada bayi baru lahir. Perawatan tali pusat secara umum bertujuan untuk mencegah terjadinya infeksi dan mempercepat putusnya tali pusat. Infeksi tali pusat pada dasarnya dapat dicegah dengan melakukan perawatan tali pusat yang baik dan benar, yaitu dengan prinsip perawatan kering dan bersih. Banyak pendapat tentang cara terbaik untuk merawat tali pusat. ${ }^{(1)}$

Tahun 2010 Worid Health Organization (WHO) menemukan angka kematian bayi sebesar 560.000 yang disebabkan oleh infeksi tali pusat. Di Asia Tenggara Angka kematian bayi karena infeksi tali pusat sebesar $126.000 .^{(2)}$

Kasus tetanus neonatorum di Indonesia tahun 2014 sebanyak 84 bayi dari 15 provinsi dengan mortalitas 54 bayi. Faktor risiko mortalitas tersebut antara lain perawatan tali pusat dengan alkohol, iodium, tradisional, serta perawatan tali pusat yang tidak diketahui caranya. Case Fatality Rate (CFR) tetanus neonatorum pada tahun 2014 sebesar 64,3\%, meningkat dibandingkan tahun 2013 sebesar $53,8 \% .^{(3)}$

Salah satu upaya yang dapat dilakukan untuk menurunkan angka kesakitan dan angka kematian bayi adalah dengan memberikan pelayanan kesehatan yang efektif pada masyarakat tentang perawatan 
tali pusat bayi. Dalam melaksanakan upaya tersebut diperlukan sumber daya manusia yang mempunyai kemampuan untuk memberikan pelayanan yang berkualitas, yaitu dengan memberikan penyuluhan tentang kesehatan kepada masyarakat, sehingga pengetahuan yang dimiliki oleh masyarakat diharapkan dapat memengaruhi perilaku masyarakat terhadap kesehatan. ${ }^{(4)}$

Perawatan tali pusat sangat penting dilakukan terutama oleh ibu melahirkan karena ibu yang lebih mengetahui perkembangan bayi ssetiap harinya. Perawatan tali pusat yang baik seperti menghindari penggunaan bedak dermatol, dan penggunaan ramuan tradisional yang kurang memperhatikan kesterilannya sangat penting. Kenyataan di masyarakat masih banyak ibu yang mengikuti tradisi budaya yang ada di masyarakat. Misalnya meletakkan atau membalutkan ramuan tradisonal ke tali pusat supaya tali pusat cepat lepas (puput) atau ditutupi dengan koin agar pusat tidak bodong. Padahal tindakan tersebut tidak perlu dilakukan justru dapat membahayakan. Sehingga jika diberikan ramuan, bubuk kopi, koin dapat menularkan kuman. Akibatnya terjadi infeksi atau tetanus yang sangat membahayakan karena tingkat mortalitasnya tinggi. ${ }^{(5)}$

Perawatan tali pusat untuk bayi baru lahir yaitu dengan tidak membungkus puntung tali pusat atau perut bayi dan tidak mengoleskan cairan atau bahan apapun ke puntung tali pusat. Upaya untuk mencegah infeksi tali pusat sesungguhnya merupakan tindakan sederhana, yang penting adalah tali pusat dan daerah sekitarnya selalu bersih dan kering. Sudah banyak penelitian yang dilakukan untuk meneliti bahan yang digunakan untuk merawat tali pusat. Perawatan tali pusat secara medis menggunakan bahan antiseptik yang meliputi alkohol $70 \%$ atau antimikrobial seperti povidon-iodin 10\% (Betadine), Klorheksidin, Iodium Tinstor dan lain-lain yang disebut sebagai cara modern. Sedangkan perawatan tali pusat metode tradisional menggunakan madu, Minyak Ghee (India) atau kolostrum ASI. $^{(6)}$

Berbagai penelitian memperlihatkan bahwa dengan membiarkan tali pusat mengering, tidak ditutup, hanya dibersihkan setiap hari dengan air bersih, merupakan cara paling efektif dan murah untuk perawatan tali pusat. ${ }^{(7)}$

\section{Metode Pengabdian}

Kegiatan pengabdian kepada masyarakat dilaksanakan di Desa Ruta, pada bulan Juli 2019. Sasaran dari kegiatan pengabdian masyarakat ini adalah para ibu nifas yang berada di lokasi penelitian. Kegiatan pengabdian ini berupa penyuluhan pada ibu nifas mengenai perawatan tali pusat menggunakan media leaflet, laptop, LCD, kuesioner dan speaker. Pada kegiatan pengumpulan data akan dilakukan pre-test dan post-test mengenai pengetahuan sampel. Teknik pengumpulan data yang digunakan adalah teknik sampling aksidental yaitu siapa saja yang secara kebetulan bertemu dengan peneliti dapat digunakan sebagai sampel penelitian sesuai dengan kriteria inklusi dan eksklusinya. Dalam kegiatan pengabdian masyarakat ini pengolahan dan analisis data menggunakan analisis univariat, hasil kuesioner yang didapatkan akan di tabulasi kemudian di analisis secara manual dan dibuatkan pembahasan. 


\section{Hasil dan Pembahasan}

\section{A. Hasil}

\section{Hasil Pre-test dan Post-test Pengetahuan Ibu Nifas Mengenai Tali Pusat}

Dari hasil data penelitian menunjukan bahwa adanya peningkatan pengetahuan ibu tentang perawatan tali pusat pada bayi sebesar $86,7 \%$. Pengetahuan ibu mengenai perawatan tali pusat yang benar saat pre-test sebesar 20,0\% setelah dilakukan penyuluhan tentang perawatan tali pusat pada bayi, pemahaman dan pengetahuan meningkat sehingga nilai post-test naik yaitu sebesar $86,7 \%$. Data selengkapnya dapat dilihat pada tabel 1.

Tabel 1. Hasil Pre-test dan Post-test Pengetahuan Ibu Nifas Mengenai Tali Pusat

\begin{tabular}{ccccccc}
\hline \multirow{2}{*}{ No } & \multicolumn{3}{c}{ Pre-test } & \multicolumn{3}{c}{ Post-test } \\
\cline { 2 - 7 } & Pengetahuan & $\mathrm{f}$ & $\%$ & Pengetahuan & $\mathrm{f}$ & $\%$ \\
\hline 1 & Baik & 3 & 20,0 & Baik & 13 & 86,7 \\
2 & Kurang & 12 & 80,0 & Kurang & 2 & 13,3 \\
\hline & Jumlah & 15 & 100,0 & Jumlah & 15 & 100,0 \\
\hline
\end{tabular}

\section{B. Pembahasan}

Pada kegiatan ini rendahnya pengetahuan ibu dapat dipengaruhi oleh ketidaktahuan ibu tentang perawatan tali pusat yang benar, serta kepercayaan di daerah setempat tentang perawatan tali pusat. Rendahnya pengetahuan ibu tentang perawatan tali pusat yang benar dapat menyebabkan infeksi yang mengakibatkan bayi terdampak tetanus noenatoru dan berakir dengan kematian.

Dalam kegiatan pengabdian ini masyarakat aktif dalam mengikuti kegiatan penyuluhan dari awal dilaksanakan sampai akhir dilaksanakan. Peserta pengabmas aktif dalam sesi tanya jawab. Kegiatan pengabmas ini selain memberikan penambahan pengetahuan dan wawasan juga memperbaiki pola pikir ibu mengenai teknik perawatan tali pusat yang benar.

Sebelum dilakukan penyuluhan terlebih dulu dilakukan pre-test tentang perawatan tali pusat yang kuesionernya disebarkan oleh mahasiswa lalu dilakukan sesi penyuluhan dengan memberikan leaflet terlebih dahulu lalu memulai materi penyuluhan yang dibawakan oleh mahasiswa. Setelah sesi materi tiba sesi tanya jawab dengan menggunakan metode diskusi aktif yang dijawab oleh dosen. Setelah sesi diskusi mahasiswa menyebar kuesioner kembali untuk melakukan evaluasi pengetahuan pada ibu. Kemudian hasil data penelitian dibuatkan tabulasi data dan dilakukan analisis menggunakan hitungan manual lalu hasil hitungan manual dideskripsikan.

Dengan adanya penyuluhan ini maka wawasan ibu mengenai perawatan tali pusat bayi yang baik dan benar menjadi meningkat. Diharapkan dengan adanya pengabdian ini dapat mengubah kebiasaan yang buruk mengenai perawatan tali pusat pada bayi.

\section{Simpulan dan Saran}

Berdasarkan kegiatan penyuluhan ini didapatkan hasil adanya peningkatan kenaikan pengetahuan tentang perawatan tali pusat yang baik sebesar $86,7 \%$. Faktor yang memengaruhi pengetahuan ibu 
tentang perawatan tali pusat bayi ialah sampel tidak mencari tahu informasi mengenai perawatan tali pusat yang baik dan benar serta ibu masih mengikuti kepercayaan dan kebiasaan di daerah setempat.

Sehingga disarankan bahwa penyuluhan mengenai perawatan tali pusat yang baik dan benar dapat dilakukan menyeluruh dan diharapkan dengan adanya penyuluhan ini pemahaman dan wawasan ibu mengenai perawatan tali pusat dapat bertambah. Dan dapat menyadarkan ibu untuk tetap memperhatikan kebersihan bayi.

\section{Daftar Pustaka}

1. Permanasari, D.K., Susyanto, B.E. Perawatan Tali Pusat Terbuka, Perawatan Tali Pusat Tertutup, Lama Waktu Pelepasan. Undergraduate Theses from YOPTUMYFKPP. 2009. 1 (1), 1-2.

2. Salam, Affyus. Kesehatan Bayi Baru Lahir. Jakarta. Rajawali pers.2008

3. Balitbangkes. Riset Kesehatan Dasar (Riskesdas) 2013. Kemenkes RI. Jakarta.2013 Tersedia di : http://www. depkes.go.id/resources/download/gen eral/Hasil\%20Riskesdas\%202013.pdf -

4. Ikatan Dokter Anak Indonesia (IDAI). Buku Ajar Respirologi Anak, Edisi Pertama. Jakarta: Badan Penerbit Ikatan Dokter Anak Indonesia. 2011

5. Zacharia. Tata Cara Pemotongan Tali Pusat. Yogyakarta: Nuha Medika.2016

6. JNPK-KR. Asuhan Esensial, Pencegahan dan Penanggulangan Segera Komplikasi Persalinan Dan Bayi Baru Lahir. Depkes RI. Jakarta: 189. 2008

7. Sodikin. Buku Saku Perawatan Tali Pusat. EGC. Jakarta.2009 